\title{
A New Korean Defined Contribution Plan Framework to Enhance Retirement Income Security: Combining Lifecycle Funds with Compulsory Annuitisation
}

\author{
Kyonghee Lee ${ }^{\mathrm{a}}$ and Jooho Sung ${ }^{\mathrm{b}}$ \\ ${ }^{a}$ Korea Insurance Research Institute, Seoul, South Korea. \\ E-mail: khlee@kiri.or.kr \\ ${ }^{\mathrm{b}}$ Department of Finance and Insurance, Kyung-Hee University, Seoul, South Korea. \\ E-mail: jhsung@khu.ac.kr
}

In this paper, the intension is to construct a new Korean defined contribution operation structure that better meets retirement income security by integrating accumulation and payout phases. For this, two approaches are compared: a lump sum withdrawal programme supported by a principal preservation fund (i.e. current approach), and the combination of compulsory annuitisation with lifecycle funds (i.e. alternative approach). We set benchmark incomes, annuity incomes from the immediate life annuity policy, purchasable at retirement with the accumulated assets of lifecycle funds. The above two approaches are then assessed in terms of the probability of shortfall employed here to measure the longevity risk, at a Value-at-Risk of 50, 75 and 95 per cent, respectively. Consequently, it is shown that the alternative approach provides better retirement income security than the current approach.

The Geneva Papers (2010) 35, S50-S67. doi:10.1057/gpp.2010.33;

published online 15 December 2010

Keywords: Korean DC pension system; investment restriction; accumulation and payout phases; lifecycle funds; purchased life annuities; probability of shortfall

\section{Introduction}

As in many developed countries with an ageing population, this problem is currently emerging as one of the critical issues in Korea, especially in the Korean welfare system, including the public pension system. From the 1970 s to 2008 , Korea's fertility rate fell sharply from 4.53 to 1.19 , which is the lowest in the Organisation for Economic Co-operation and Development (OECD). During the same period, life expectancy increased from 62.7 years in the 1970s to 80.1 years in 2008, a figure that is above the OECD average. The dependency ratio is expected to rise to 70 per cent by 2038 .

A rapidly ageing population led the Korean government to implement a private retirement pension programme under the Retirement Benefit Security Act in December 2005. However, due to strong restrictions imposed on investing in risky assets, the asset allocation of pension funds is heavily concentrated in products with low risk and low return. The share of principal and interest guarantee products amounted to 64.8 per cent of the investment assets in defined contribution (DC) plans. In contrast to the accumulation phase, a one-time lump sum payment is permitted 
without restriction during the payout phase, and this is expected to be an appealing option for a majority of retirees.

Taking into account the international trend of shifting from a defined benefit (DB) plan to a DC plan, Korean employees are also more likely to rely on DC types. Generally, in the DC plan, retirement income depends on the investment results during the accumulation phase, as well as on the distribution strategies during the payout phase. In this respect, an effective plan design can facilitate the accumulation of assets during the working period and the hedging of longevity risks after retirement.

The main purpose of this paper is to suggest how the Korean pension framework shapes both accumulation and payout structures. It presents two approaches in order to propose a more effective system: the current approach and the alternative approach. The current approach is based on a lump sum withdrawal programme supported by a principal preservation fund. The alternative approach, on the other hand, assumes compulsory annuitisation combined with lifecycle funds. The paper proceeds in two stages. First, it presents the performances of accumulated assets at the time of retirement. Second, it evaluates the distribution of the lump sum programme against the benchmark annuity converted from lifecycle funds, using the probability of shortfall (PoS).

This paper is organised as follows. The following section reviews the Korean pension system, focusing on its regulatory framework by examining the current investment restrictions and payout options. The next section describes the data and methodology comparing the two approaches, followed by the results of simulations. The final section presents conclusions and limitations.

\section{The Korean pension system}

\section{Overview}

The private Korean pension system consists of three categories, as presented in Figure 1. Under the retirement lump sum system, external funding schemes, called retirement insurance or trust, were established in 1999 to protect the vesting right of employees, and are currently part of a transitory system expected to be terminated by the end of 2010. In order to improve retirement income security, a new pension system was implemented in December 2005, in which employers and employees are free to choose the DB or DC plan they want. In particular, micro-firms with fewer than ten employees are allowed to offer Individual Retirement Accounts functioning in the manner consistent with the DC plan. These accounts are subject to the same regulatory treatments as the DC plans.

The Korean pension plan differs from traditional European pension plans regarding benefit design and payment structure, as shown in Table 1 and Figure 2. It allows only contract-type (not fund-type) that pension funds must be managed by separate financial institutions, which can be banks, insurance companies and securities firms. All pension plans are required to guarantee a minimum level. That is, DB plans must provide a minimum benefit equivalent to one month's final salary per year of service, which is the same as the generally well-known pension equity plans. In the case of DC plans, employers must contribute at least one month's wage, that is, 8.3 per cent of 


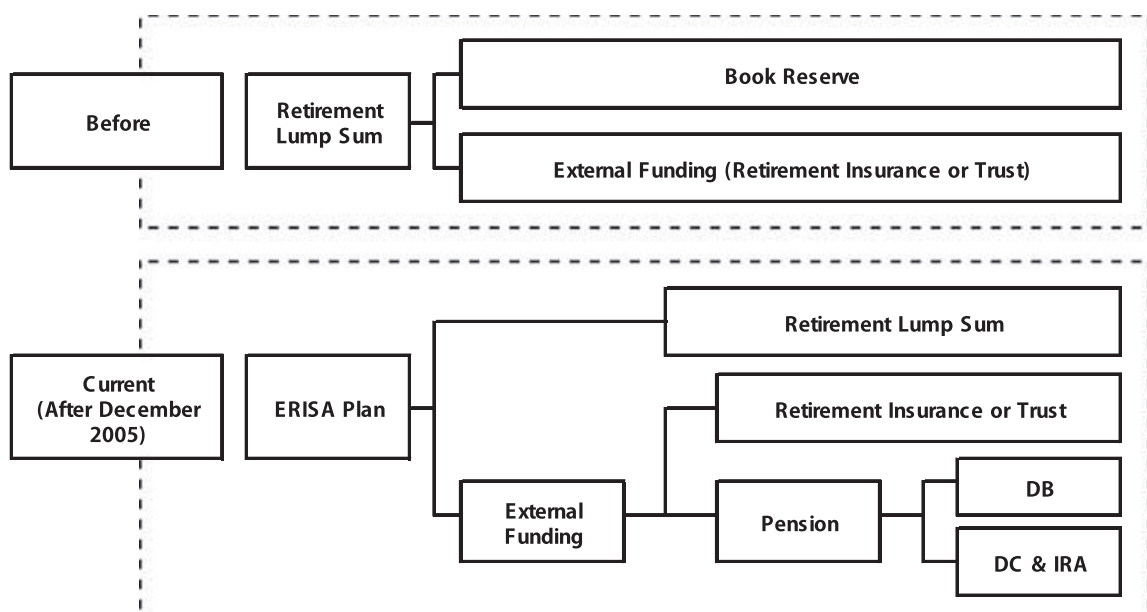

Figure 1. Brief history of retirement financial system in Korea.

Table 1 Comparison of traditional and Korean pension plans

\begin{tabular}{|c|c|c|c|}
\hline & Traditional pension plan & Korean pension plan & Comments \\
\hline Plan offering & $\begin{array}{l}\text { Voluntary (Independent } \\
\text { trust fund type) }\end{array}$ & Mandatory (contract type ${ }^{\mathrm{a}}$ ) & $\begin{array}{l}\text { Provide among } \mathrm{DB}, \mathrm{DC} \\
\text { and book reserving }\end{array}$ \\
\hline Benefit design & Voluntary & $\begin{array}{l}\text { Minimum level } \\
\text { DB: one month's final wage } \\
\text { per year of service } \\
\text { DC: one month's pay for } \\
\text { each year of service }\end{array}$ & $\begin{array}{l}\text { Final pay for DB and } \\
\text { annual pay for DC }\end{array}$ \\
\hline $\begin{array}{l}\text { Common payment } \\
\text { form }\end{array}$ & $\begin{array}{l}\text { Annuity for DB and } \\
\text { lump sum for DC }\end{array}$ & Focus on lump sum & $\begin{array}{l}\text { Retirement annuity } \\
\text { option (at least } 10 \text {-year } \\
\text { service, age } 55 \text { or more) }\end{array}$ \\
\hline
\end{tabular}

${ }^{a}$ Contract type means that a pension fund is established as a separate account managed by financial institutions, that is, the contract between sponsors/members and financial institutions. This governance form may be limited to the representation of beneficiary interests.

each year's salary. At retirement, the benefit of DB is measured as 8.3 per cent of the final salary multiplied by years of service. However, the benefit of DC is not guaranteed because employees bear the investment risk during the accumulation phase.

\section{Investment and payout regulation}

Investment regulation controls both the type and the limit of risky assets applicable to the assets of the DB and DC plans. The DC plan is clearly regulated much more heavily than the DB plan. As for the DC plan, an employee is responsible for investment performance. The permitted types of securities are very conservative, for example bonds issued by the government and by companies of OECD members, etc. 


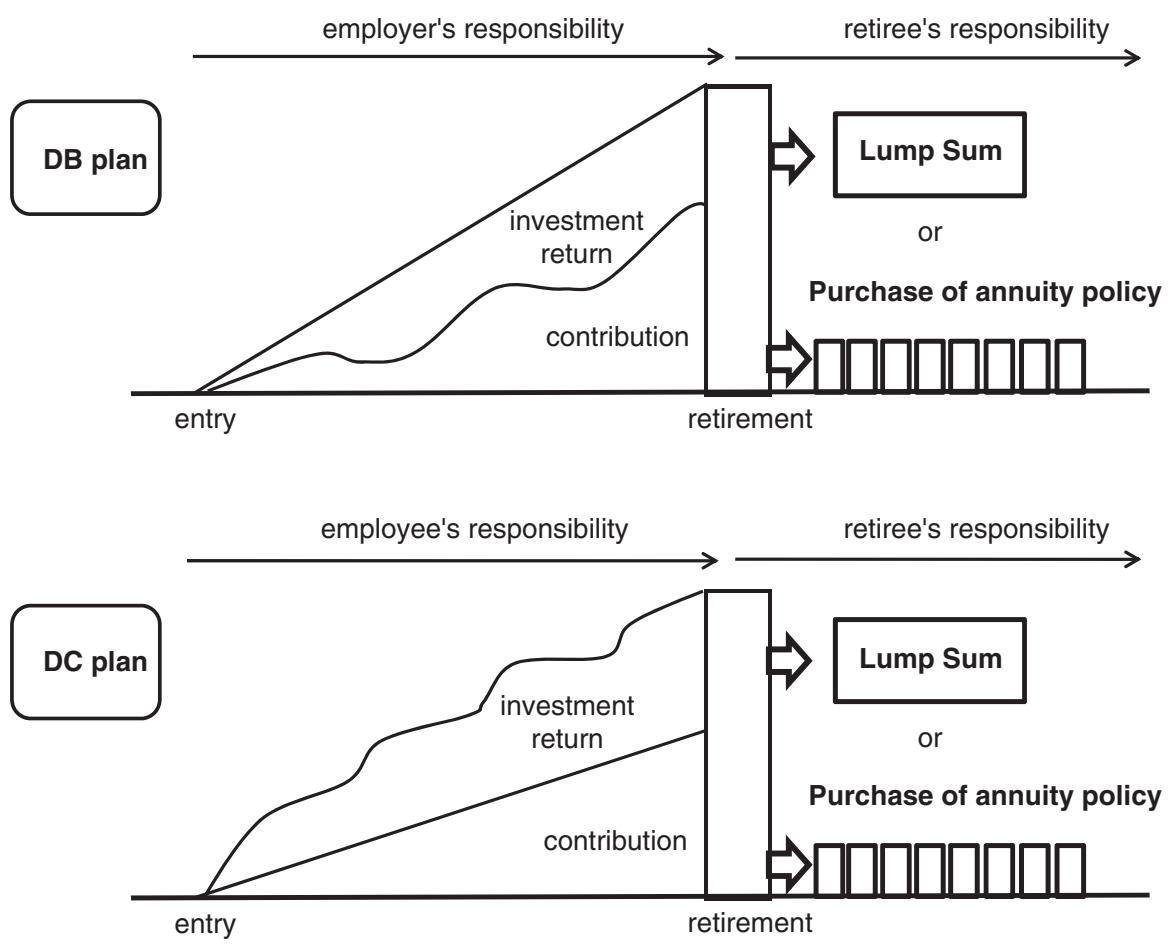

Figure 2. Comparison of payout options in the Korean pension plan.

Table 2 Investment limit restrictions in the Korean DC plan

\begin{tabular}{|c|c|c|}
\hline & Risky asset & Investment limit \\
\hline Direct investment & $\begin{array}{l}\text { - Stocks } \\
\text { - Convertible bonds, bonds with warrant } \\
\text { - Subordinated bonds }\end{array}$ & Not permitted \\
\hline \multirow[t]{2}{*}{$\begin{array}{l}\text { Indirect investment } \\
\text { (funds) }\end{array}$} & $\begin{array}{l}\text { - } \quad \text { Equity-type }(\text { share of stocks } \geqslant 60 \%) \\
\text { - Hybrid-type }(40 \%<\text { share of stocks }<60 \%) \\
\text { - } \text { Derivative, real estate, etc. }\end{array}$ & Not permitted \\
\hline & - Bond-led hybrid-type (share of stocks $\leqslant 40 \%$ ) & Permitted \\
\hline Foreign investment & $\begin{array}{l}\text { - Bonds with eligible grade } \\
\text { - Indirect investment securities (funds) }\end{array}$ & Permitted up to $30 \%$ \\
\hline
\end{tabular}

Table 2 shows the investment restrictions on the DC plan. The investment limit is determined based on the total assets for each pension account holder. Direct stock investments, indirect equity-type funds that allocate over 60 per cent of the stock (i.e., equity funds), and indirect hybrid-type funds that allocate between 40 and 60 per cent of 
the stock (i.e., mixed funds) are prohibited. Among indirect investments, only bond-led hybrid-type funds whose total investment limit for risky assets is 40 per cent are permitted.

Unlike its regulations on investments, there are no restrictions for the payout phase. Figure 2 shows the retirement pension payout options. For the payout stage, the same regulations are applied to both the DB and DC plan. It is possible at retirement to withdraw a lump sum, or to purchase a life annuity policy that will transfer both longevity risk and investment risk to a life office. A lump sum is paid to employees who are not entitled to receive an annuity, or to those who simply want to receive it. To be qualified for the annuity payment, an employee aged 55 or above must have participated in the plan for ten years or more, and accept annuity payments for five years or longer.

In traditional DB and DC plans, longevity risks are assumed by employers and employees, respectively. However, in the Korean pension system, employees assume longevity risks in both the DB and DC plan, as illustrated in Figure 2.

\section{Asset allocation of DC plan}

In DC plans, setting up an asset-allocation strategy is much more important than setting up an asset-returns model. According to the studies by Brinson et al., ${ }^{1}$ more than 90 per cent of the variability in a pension plan's performance is the result of an asset allocation policy. Figure 3 illustrates the asset allocation of the DC plan in Korea as of June 2009. The main characteristic of asset allocation is represented by the heavy concentration of low-risk-low-return-type asset classes: the shares of principal and interest guarantee products reached 64.8 per cent of the total assets. These products include deposits, guaranteed interest contracts (GICs), bonds, etc., and above all, bank deposits and interest-sensitive insurances.

In terms of investment maturity, deposits and GICs are renewed every year, and are also oriented in short-term saving arrangements. In contrast to Korea, the general composition of the DC pension fund portfolio in developed countries is investing mainly in stocks over 60 per cent, bonds 20 per cent and other alternatives 20 per cent, according to the survey by Watson Wyatt. ${ }^{2}$ Therefore, the short-term saving tendency of the Korean pension plan could be justified on the grounds that the pension service provider is not unwilling to recommend the certainty of a reliable return of the accumulated pension assets due to regulatory investment restrictions, even though there may be a substantial sacrifice of the long-term upside potential.

Under the governmental regulations, investable asset classes are specifically listed; in addition, the direct investment of risky assets is not permitted, as given in Table 2 . Although the investment of risky assets is allowed via the indirect investment method, equity-type and hybrid-type funds are prohibited, and only the bond-led hybrid-type fund is permitted. With the investment limit restriction, an employee who has a tolerance for high risk can invest up to 40 per cent in stocks through the indirect investment. Moreover, at least one principal and interest guarantee product must be suggested as investment options in the DC plan. Under these circumstances, employers

\footnotetext{
${ }^{1}$ Brinson et al. (1986, 1991).

${ }^{2}$ Watson Wyatt (2009).
} 


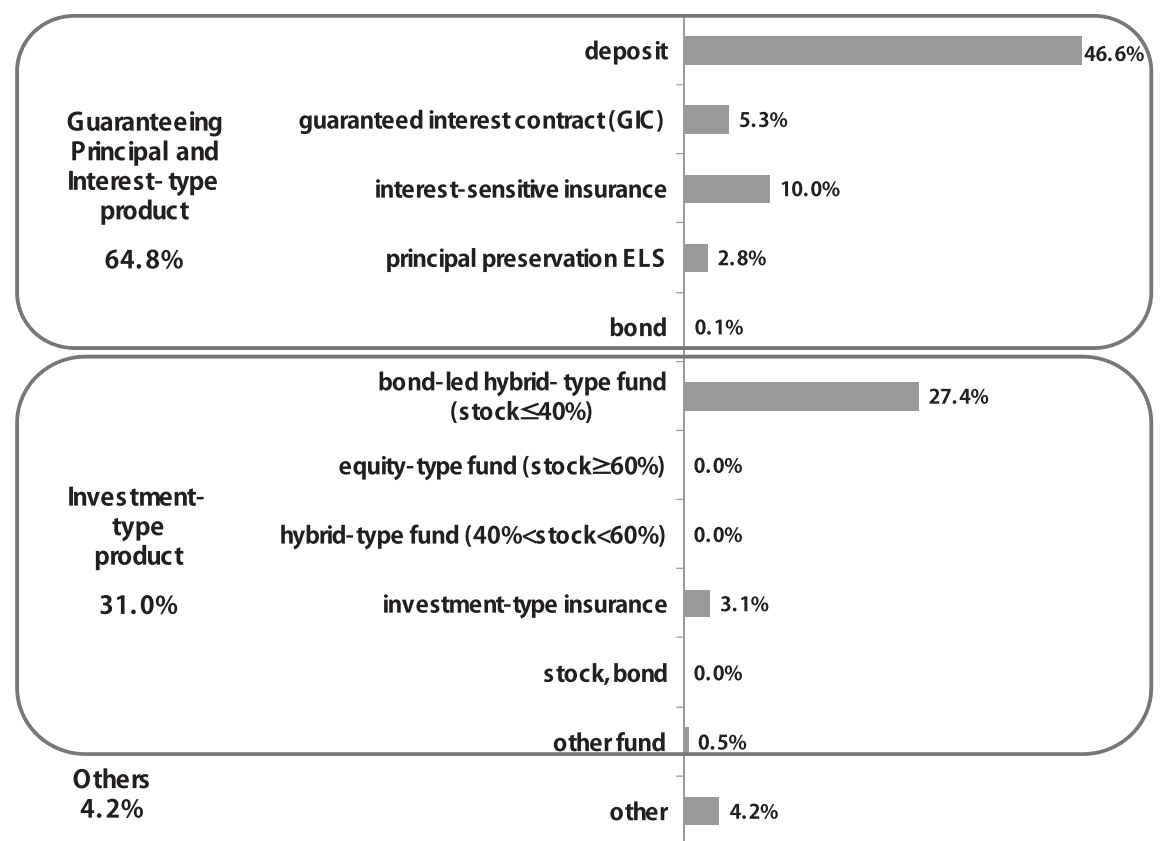

Figure 3. Asset allocation of Korean DC plans (as of June 2009).

Source: Korean Ministry of Labor.

and employees are inclined to accept the principal and interest guarantee product as a default investment option, even though they have no experience with long-term investment because of the short history of the pension system. In addition, the Korean pension system is operated by external service providers (i.e., financial institutions). Therefore, service providers are actually willing to suggest their own products to increase their profits: that is, deposits for banks, GICs for insurance companies, and mutual funds for securities firms.

As a whole, the strict investment limit restrictions and suggestion of the principal-interest guarantee products could be said to result in the extremely conservative asset allocation.

\section{A new DC framework for retirement income security}

\section{Design for simulation analysis and data}

\section{Design for simulation analysis}

In DC plans, an employee bears investment and longevity risks over accumulation and payout stages. The strict regulations of the Korean DC system may impose substantial costs and risks on employees. This section evaluates the ineffectiveness of the current DC system and then suggests a new DC framework for improving retirement income security.

The analysis used in this paper is based on the following assumptions. An employee participates in a DC plan at the age of 25 and retires at 55, 60 and 65, respectively. The employee's starting wage is 100 , his expected nominal wage increase is 7.0 per cent 
Table 3 Design framework

\begin{tabular}{lll}
\hline & Accumulation phase & Payout phase \\
\hline Current approach & $\begin{array}{l}\text { Strict investment limit restriction for } \\
\text { risky assets } \\
\text { Oriented in principal preservation } \\
\text { products }\end{array}$ & No regulation \\
Alternative approach & $\begin{array}{l}\text { Abolishes investment restriction } \\
\text { Suggests default lifecycle funds }\end{array}$ & Compulsory annuitisation \\
Criteria of proper policy & $\begin{array}{l}\text { Size of accumulated assets at } \\
\text { retirement }\end{array}$ & Shortfall probability \\
\hline
\end{tabular}

per year and the sponsoring employer provides his mandatory contribution amounted to 8.3 per cent of his wage annually. These assumptions reflect the reality of a general Korean workplace. Compared to advanced countries, Korean employees have a relatively short contribution period because of early retirement age (NRA). Although it varies by types of occupation, the NRA is uniformly set at around 55 .

The paper first analyses the security of retirement income in the current environments, and then compares this with the alternative DC pension system, suggested below. Table 3 illustrates an alternative framework for the accumulation phase and payout phase: combining default life cycle funds with compulsory annuitisation.

Taking the policies of advanced countries into consideration, an alternative approach to the accumulation phase has been designed. In the U.K., U.S. and Australia, employers guide employees through the default investment options during the accumulation phase. Many pension plans suggest a default investment option in which an employee's contribution is automatically set up if the employee does not actively choose a particular option.

In practice, many employees are inclined to passively adopt the default investment options that exist in their plans. For example, Basu and Drew ${ }^{3}$ review Australian data on the tendency of employees to accept default investment options, and find that around two thirds of all pension plans are invested in default options.

On the other hand, the 2006 Pension Protection Act in the U.S. was enacted in response to the needs of diversified default investment options. In addition, a default fund has been compulsorily offered within stakeholder DC plans in the U.K. since April 2005.

One tentative conclusion that could be drawn from the above trends is that the goal of default investment is to facilitate retirement income adequacy for employees, particularly in a case where they increasingly rely on DC plans. Recently, lifecycle funds have been becoming more popular among a number of default investment options. ${ }^{4}$ Furthermore, the $2009401(\mathrm{k})$ benchmarking survey shows that 68 per cent of

\footnotetext{
${ }^{3}$ Basu and Drew (2006).

${ }^{4}$ In the U.S., lifecycle funds have grown rapidly since their introduction in the early 1990s. Total assets of lifecycle funds exceeded US\$200 billion in 2008 (Marcks, 2009).
} 
respondents chose lifecycle funds. In general, lifecycle funds are designed to systematically reduce portfolio risks because the composition of the pension fund portfolio shifts away from riskier stocks and moves towards conservative bonds as the employee's age gets close to NRA. As supporting evidence of the above, reference is made to the study by Byrne et al., ${ }^{5}$ in which they find that the use of lifecycle funds reduces investment risk as the planned retirement date approaches.

Next, consideration is given to the disadvantages of lump sum payments. Under the current system that allows lump sum option without restriction, the majority of retirees are highly expected to withdraw accumulated assets in a single payment. Glickman and Kuehneman ${ }^{6}$ find such evidence of preference in the fact that over 90 per cent of retirees in the U.S. are willing to select lump sums in their DC plans. Although the lump sum payment is fully flexible and provides complete liquidity, an employee requires strong financial discipline and knowledge of life expectancy in order to efficiently manage his assets. In reality, however, studies in financial behaviour show that the existence of inertia, information bias and a lack of knowledge often contribute to undesirable results, such as insolvency. Therefore, many studies, such as Bardner and Odean, Brown et al. ${ }^{7}$ and Drinkwater et al., ${ }^{8}$ have supported the necessity for restrictions on payout options, especially lump sum payments.

To do so, policy-makers in many European countries require that accumulated assets be annuitised within a certain age. In the U.K., for example, by the age of 75, an annuity must be purchased at a minimum of 75 per cent in accumulated assets. Such annuities are usually called compulsory purchased annuities.

Lastly, the current system is numerically compared with the newly suggested approach, conceptually explained above, through a two-stage analysis. In the first stage, the accumulated assets are calculated 30, 35 and 40 years in the future. In the current investment system, it is assumed that the principal preservation fund comprises a 70 per cent deposit and a 30 per cent bond-led hybrid-type fund. This is based on the assumption that employees' inclination towards principal-interest guarantee products will continue in the future.

It is assumed here that the lifecycle fund comprises stocks and bonds, and that two types of hypothetical lifecycle funds exist: the conservative path and the aggressive path. The stock allocations of lifecycle paths are shown in Figure 4. On the conservative path, the lifecycle fund starts at the age of 25, and is composed of 70 per cent stock and 30 per cent bond. By the age of 55 (i.e., accumulation period 30 years), it ends with 40 per cent stock and 60 per cent bond. As for the aggressive path, stock allocation increases at a starting point of 90 per cent and ends at 60 per cent. If the accumulation periods are getting longer (i.e., 35 or 40 years), the portion of stock is decreased and the portion of bond is increased linearly. This is an average asset allocation pattern similar to that of Ellement and Lucas, ${ }^{9}$ as well as Pang. ${ }^{10}$

\footnotetext{
${ }^{5}$ Byrne et al. (2007).

${ }^{6}$ Glickman and Kuehneman (2006).

${ }^{7}$ Brown et al. (2008).

${ }^{8}$ Drinkwater et al. (2004).

${ }^{9}$ Ellement and Lucas (2007).

${ }^{10}$ Pang (2008).
} 


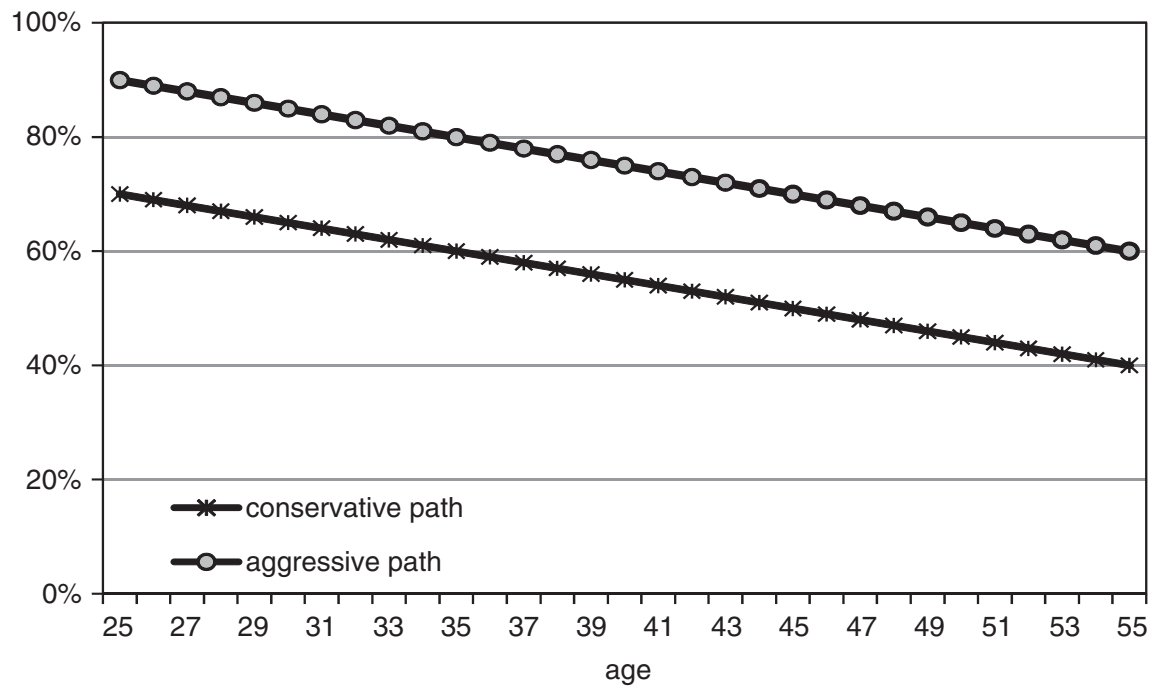

Figure 4. Stock allocation of lifecycle funds (retire at age 55).

The value of accumulated assets is assumed to evolve according to the following recursive formula: for each $t=0,1,2, \ldots$

$$
V_{t+1}=\left(V_{t}+C_{t}\right) \cdot\left(1+R_{t+1}\right) \quad \text { with the given } V_{0}
$$

where $V_{t}$ is the value of the asset portfolio at time $t$ and $C_{t}$ is the contribution, that is, 8.3 per cent of the annual salary paid in time $t . R_{t}$ represents the investment rate of return during the intervaluation period $(t, t+1)$, and depends largely on the chosen asset allocation strategy. As in Albrecht and Maurer ${ }^{11}$ and Dus et al., ${ }^{12}$ the investment rate of return follows a geometric Brownian motion. This implies that the log returns $R_{t}$ over the year are serially independent and identically normally distributed with given mean $\mu$ and volatility $\sigma . V_{t}$ is distributed log-normally, that is, $\ln \left(V_{t}\right) \sim N\left(m_{t}, v_{t}^{2}\right)$ follows a normal distribution with mean $m_{t}=\left(\mu-0.5 \sigma^{2}\right) t$ and variance $v_{t}^{2}=t \sigma^{2}$.

In the second stage, the security of retirement income is assessed. In order to measure the quantification level of retirement income security, the PoS that has been presented in Albrecht and Maurer ${ }^{11}$ and Dus et al., ${ }^{12}$ is employed here. The PoS is determined by asset-exhaustion, which has been realised at a point in time when the retiree is still alive. Albrecht and Maurer ${ }^{11}$ derive the PoS as follows:

$$
\operatorname{PoS}(R)=\sum_{t=1}^{\omega-x}{ }_{t} p_{x} \cdot P\left(\tau_{R}=t\right)
$$

\footnotetext{
11 Albrecht and Maurer (2002).

12 Dus et al. (2005).
} 
${ }_{t} p_{x}$ means the conditional probability that a retiree aged $x$ will attain age $x+t$, and is actuarially calculated according to the adopted mortality table. $\tau_{R}$ denotes the earliest point in time when consumption shortfall occurs: that is, for $u=0,1,2, \ldots$

$$
\tau_{R}=\inf \left\{u \geqslant 0 ; V_{R}(u) \leqslant 0\right\}
$$

$V_{R}(u)$ represents the value of the asset available after a fixed amount $R$ (i.e., benchmark income) is paid at the beginning of each valuation period $(u, u+1)$. The initial asset capital is defined in the form $V_{R}(0)=L S-R$ where $L S$ denotes the lump sum paid at retirement. In the payout phase, $V_{R}(u)$ is generated in the same fashion as in the accumulation phase, that is, a geometric Brownian motion.

\section{Simulation data}

As explained in Eqs 1 and 3, the accumulation process of pension assets in both the accumulation and payout phase is characterised by a geometric Brownian motion with constant drift, diffusion and correlation parameters. For the estimation of these parameters, the limited amount of historical data for Korean investment returns over the period October 1998 to June 2009 is used, since Korean bond index data is not available prior to September 1998. It is assumed here that future investment returns will behave in a manner consistent with the past stochastic trends.

Table 4 shows the investment returns and standard deviations of each asset class. The average return on short-term deposits is 5.07 per cent per annum, with a standard deviation of 1.36 per cent. The average annual stock return is 13.95 per cent, with a standard deviation of 30.65 per cent, based on the Korea Composite Stock Price Index. The bond return is 7.55 per cent on average, with a standard deviation of 3.09 per cent, based on the KSDA-Bloomberg Korean Bond Index. The correlation coefficient is nearly zero for stock and bond returns. Historically, compared to their return levels, the Korean financial market is characterised by a high level of stock volatility and a low level of bond volatility.

Although the Korean historical data period is short, the risk-adjusted return of stock is ironically similar to that in the U.S. Stout and Mitchell ${ }^{13}$ find that mean real return to large-cap stocks is 9.17 per cent and the standard deviation of real large-cap returns is 20.27 per cent, which is based on annual data over the period 1926-2004. Hence, Korea's risk-adjusted return of stock (i.e., $0.46=13.95 / 30.65$ ) is not significantly different from that of the U.S. (i.e., $0.45=9.17 / 20.27$ ).

Unlike the other asset classes, the bond-led hybrid-type fund is hypothetically composed of 60 per cent bond and 40 per cent stock, and hence the average return is calculated by 10.11 per cent, with a standard deviation of 12.51 per cent.

\footnotetext{
${ }^{13}$ Stout and Mitchell (2006).
} 
Table 4 Empirical statistics for investment returns (October 1998 - June 2009) (Unit: \%)

\begin{tabular}{lcccc}
\hline & Deposit $^{\mathrm{b}}$ & Bond-led hybrid-type fund $^{\mathrm{a}}$ & Stock $^{\mathrm{c}}$ & Bond $^{\mathrm{d}}$ \\
\hline Mean & 5.07 & 10.11 & 13.95 & 7.55 \\
Volatility (standard deviation) & 1.36 & 12.51 & 30.65 & 3.09 \\
\hline
\end{tabular}

${ }^{a}$ Bond-led hybrid-type fund assumes the hypothetical asset allocation of bond $60 \%$ and stock $40 \%$. Sources:

${ }^{\mathrm{b}}$ Bank of Korea.

${ }^{\mathrm{c}}$ Korea Composite Stock Price Index.

${ }^{\mathrm{d}}$ KSDA-Bloomberg Korean Bond Index.

\section{Simulation results}

\section{Accumulated assets}

The pension fund assets are accumulated from age 25 to NRA (i.e., 55, 60 or 65, respectively) and are rebalanced every year. Fund charges (or costs) and inflation factors are not considered, and therefore asset values are displayed in nominal terms. To generate the accumulated assets at the ages of 55, 60 and 65, 10,000 Monte Carlo simulations on the basis of Formula (1) were run.

Table 5 shows the range of the asset values simulated up to NRA at retirement for each of the three asset allocation strategies. At the end of the investment periods, the expected values of lifecycle funds dramatically surpass those of the principal preservation fund. The expected value of the lifecycle funds is approximately twice that of the principal preservation fund. Greater dispersion in accumulated assets is observed on the upside rather than the downside.

At the age of 55 , the $95^{\text {th }}$ percentile indicates that the principal preservation fund realises only 2,507, whereas lifecycle funds achieve 9,033 (in a case of the conservative path) and 14,231 (in a case of the aggressive path). Furthermore, at the $5^{\text {th }}$ percentile, the principal preservation fund realises 1,528 , and lifecycle funds realise 1,495 (in a case of the conservative path) and 1,156 (in a case of the aggressive path). Even in the worst case scenario, the lifecycle fund with the aggressive path performs close to 75 per cent of the principal preservation fund.

As shown in Table 5, investing over a much longer time horizon leads to a widening of the gap between the investment performances corresponding to each of the asset allocations. For example, at the age of 60, the average accumulated assets from the lifecycle funds $(5,905,6,413)$ are 86 and 102 per cent higher, respectively, than the principal preservation fund $(3,173)$. If the retirement age is raised to 65 , at the $25^{\text {th }}$ percentile, the lifecycle funds $(6,960,6,589)$ exceed the principal preservation fund $(4,494)$ by 55 and 47 per cent, respectively. Moreover, even at the $5^{\text {th }}$ percentile, the conservative lifecycle fund (4,322) provides higher asset accumulation than the principal preservation fund $(3,820)$.

According to the simulation results, lifecycle funds dominate more the principal preservation fund as long as the time horizon is much longer because the higher expected return of stocks limits more significantly the extent of the downside risk as time goes on. All these are clearly illustrated in Figure 5. 
Table 5 Accumulated assets at retirement by asset allocations (Unit: Korean won)

\begin{tabular}{|c|c|c|c|c|}
\hline & Percentile & $\begin{array}{c}\text { Principal } \\
\text { preservation } \\
\text { fund }\end{array}$ & $\begin{array}{l}\text { Lifecycle fund: } \\
\text { conservative path }\end{array}$ & $\begin{array}{l}\text { Lifecycle fund: } \\
\text { aggressive path }\end{array}$ \\
\hline \multirow{5}{*}{$\begin{array}{l}\text { Retire age } 55 \\
\text { (accumulate } 30 \text { years) }\end{array}$} & $95^{\text {th }}$ & 2,507 & 9,033 & 14,231 \\
\hline & $75^{\text {th }}$ & 2,170 & 5,012 & 6,177 \\
\hline & $50^{\text {th }}(50 \% \mathrm{VaR})$ & 1,955 & 3,401 & 3,595 \\
\hline & $25^{\text {th }}(75 \% \mathrm{VaR})$ & 1,763 & 2,383 & 2,188 \\
\hline & $5^{\text {th }}(95 \% \mathrm{VaR})$ & 1,528 & 1,495 & 1,156 \\
\hline \multirow{5}{*}{$\begin{array}{l}\text { Retire age } 60 \\
\text { (accumulate } 35 \text { years) }\end{array}$} & $95^{\text {th }}$ & 4,186 & 16,497 & 28,051 \\
\hline & $75^{\text {th }}$ & 3,538 & 8,793 & 11,317 \\
\hline & $50^{\text {th }}(50 \% \mathrm{VaR})$ & 3,173 & 5,905 & 6,413 \\
\hline & $25^{\text {th }}(75 \% \mathrm{VaR})$ & 2,853 & 4,108 & 3,861 \\
\hline & $5^{\text {th }}(95 \% \mathrm{VaR})$ & 2,442 & 2,551 & 1,991 \\
\hline \multirow{5}{*}{$\begin{array}{l}\text { Retire age } 65 \\
\text { (accumulate } 40 \text { years) }\end{array}$} & $95^{\text {th }}$ & 6,779 & 28,262 & 51,269 \\
\hline & $75^{\text {th }}$ & 5,680 & 15,160 & 20,282 \\
\hline & $50^{\text {th }}(50 \% \mathrm{VaR})$ & 5,060 & 10,206 & 11,365 \\
\hline & $25^{\text {th }}(75 \% \mathrm{VaR})$ & 4,494 & 6,960 & 6,589 \\
\hline & $5^{\text {th }}(95 \% \mathrm{VaR})$ & 3,820 & 4,322 & 3,372 \\
\hline
\end{tabular}

Source: Authors' calculations.

Figure 5 shows that lifecycle funds could ultimately produce greater asset accumulation through more risky asset allocations over long time horizons. In particular, the aggressive path is analysed to provide more significant upside potentials than the conservative path. Accordingly, the conservative strategy would appear to be appropriate only for employees whose attitude to the downside risk is not able to tolerate short-term volatility.

In summary, all these results demonstrate that a principal preservation fund is not suitable for DC members on the grounds that the pension fund is one of the longest investment vehicles. Thus, the asset allocation for securing the principal and market deposit interest, the current dominant choice in Korea, would be regarded as an extremely inefficient investment strategy: that is, an employee, with long time horizons, may sacrifice the chance of substantial recovery from large investment losses.

As generally accepted, the ultimate objective of portfolio management in DC plans is to secure the stable income stream during the retirement period. Thus, in the next section, the PoS for assessing the extent to which this aim can be achieved for each payout option is employed and calculated.

\section{Probability of shortfall}

As defined in Eq. 2, the PoS has been used to measure the shortfall/longevity risk during the retirement period that a retiree will outlive the constant income stream by the accumulated assets: hereby, this measure will be utilised as the key risk index of the non-annuitised payout option, especially lump sum payment programmes such as Korea's. Similar to the studies performed by Albrecht and Maurer ${ }^{13}$ and Dus et al., ${ }^{14}$ in this paper the fixed annuity income from the immediate life annuity policy 


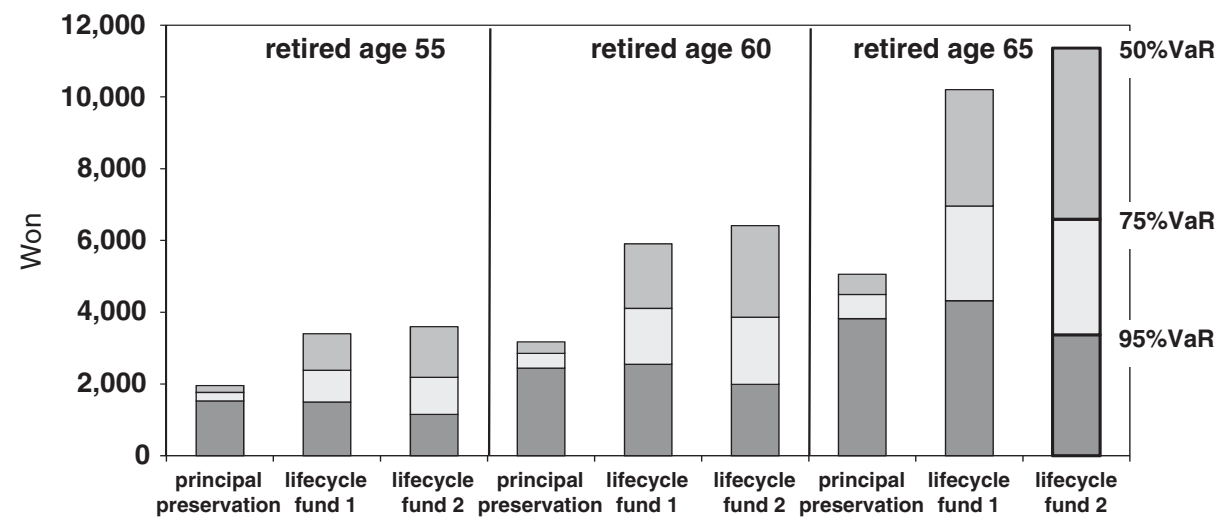

Figure 5. Simulation results of accumulated assets by each asset allocation.

Note: Lifecycle fund 1 and lifecycle 2 indicate the conservative path and aggressive path, respectively.

purchasable at retirement with the accumulated assets of lifecycle funds was chosen as a benchmark income.

First, coping with the wide range of simulation outputs, the cumulative distributions of the possible benchmark incomes are plotted. In order to make a suitable comparison between payout options such as non-annuitisation and compulsory annuitisation, Value-at-Risk (VaR) at the (100-i) per cent confidence level is adopted, in which $i$ denotes the $i^{\text {th }}$ percentile of the accumulated asset distribution in Table 5 . The primary results, given in Table 6, are summarised into the calculation of the PoS at levels of 50 per cent, 75 per cent, 95 per cent $\mathrm{VaR}$ on the basis of the accumulated asset at retirement age.

As shown in Table 6, the non-annuitisation (i.e., current approach) is highly exposed to the shortfall risk, whereas the compulsory annuitisation (i.e., alternative approach) is fully protected against the risk by purchasing an immediate life annuity. Going into detail, a retiree, with lump sum 1,955 by his principle preservation fund, invests in the recursive form of $V_{R}(u)$ defined in Eq. 3 after the annual withdrawal of the benchmark income $R$ (203.4 or 215.0) provided from an immediate life annuity contract with assumed interest rate 4.5 per cent and lump sum $(3,401$ or 3,595$)$ by his lifecycle fund: the lump sum values each are given in Table 5.

In order to obtain the PoS in the table, at each retirement age 10,000 simulations are carried out. In contrast to the accumulation phase, the simulations in this payout phase are performed on a single asset allocation composed of 60 per cent stocks and 40 per cent bonds; in particular, this allocation is based on the common conclusion of previous studies, such as Bengen, ${ }^{14}$ Stout and Mitchell, ${ }^{13}$ Ervin et al. ${ }^{15}$ and Ibbotson Associates. ${ }^{16}$ The PoS results demonstrate that the

\footnotetext{
${ }^{14}$ Bengen (1994).

${ }^{15}$ Ervin et al. (2005).

${ }^{16}$ Ibbotson Associates (2005).
} 
Table 6 Probabilities of shortfall (PoS) with respect to benchmark incomes (Unit: Korean won, \%)

\begin{tabular}{|c|c|c|c|c|c|c|}
\hline & \multicolumn{2}{|c|}{$50 \% V a R^{\mathrm{a}}$} & \multicolumn{2}{|c|}{$75 \% \mathrm{VaR}$} & \multicolumn{2}{|c|}{$95 \% \mathrm{VaR}$} \\
\hline & Withdrawal $^{\mathrm{b}}$ & $P o S^{\mathrm{c}}$ & Withdrawal & $P o S$ & Withdrawal & PoS \\
\hline \multicolumn{7}{|c|}{ Panel A: Assumed interest rate $\mathrm{d}^{\mathrm{d}}=4.5 \%$} \\
\hline \multicolumn{7}{|c|}{ In a case of conservative lifecycle fund } \\
\hline Retire at 55 & 203.4 & 60.7 & 142.5 & 13.1 & 89.4 & 11.8 \\
\hline 60 & 381.4 & 66.1 & 265.3 & 41.0 & 164.8 & 16.8 \\
\hline 65 & 727.8 & 76.6 & 496.3 & 52.8 & 308.2 & 24.5 \\
\hline \multicolumn{7}{|c|}{ In a case of aggressive lifecycle fund } \\
\hline Retire at 55 & 215.0 & 65.8 & 130.8 & 9.5 & 69.1 & 4.6 \\
\hline 60 & 414.2 & 73.4 & 249.4 & 35.9 & 128.6 & 6.8 \\
\hline 65 & 810.5 & 83.7 & 469.9 & 46.7 & 240.5 & 10.2 \\
\hline \multicolumn{7}{|c|}{ Panel B: Assumed interest rate $=4.0 \%$} \\
\hline \multicolumn{7}{|c|}{ In a case of conservative lifecycle fund } \\
\hline Retire at 55 & 191.8 & 50.5 & 134.3 & 10.9 & 84.3 & 9.5 \\
\hline 60 & 361.9 & 61.7 & 251.8 & 36.7 & 156.3 & 14.1 \\
\hline 65 & 695.2 & 68.0 & 474.1 & 47.9 & 294.4 & 20.7 \\
\hline \multicolumn{7}{|c|}{ In a case of aggressive lifecycle fund } \\
\hline Retire at 55 & 202.8 & 55.7 & 123.4 & 7.6 & 65.2 & 3.6 \\
\hline 60 & 393.0 & 69.0 & 236.6 & 31.3 & 122.0 & 5.1 \\
\hline 65 & 774.2 & 80.7 & 448.8 & 42.2 & 229.7 & 8.6 \\
\hline
\end{tabular}

${ }^{\mathrm{a}} \mathrm{VaR}$ is defined on the basis of the accumulated asset at retirement age.

${ }^{\mathrm{b}}$ Withdrawal income from the principal preservation fund is set to be the same amount as the benchmark income provided by (conservative and aggressive) lifecycle funds.

${ }^{c} \mathrm{PoS}$ is the Probability of shortfall.

${ }^{\mathrm{d}}$ Assumed interest rate is the discount rate adopted for converting the accumulated lump sum into immediate constant life annuity.

Source: Authors' calculations.

adequacy of alternative approach, relative to the current approach, is significantly high, even though it varies with retirement age and benchmark income. For example, on the basis of long-term on average (i.e., taking 50 per cent $\mathrm{VaR}$ ), the probabilities of shortfall exceed 50 per cent (i.e., between 50.5 and 83.7 per cent), which is considered to be a fairly high level of risk. Thus, this quantitative analysis would support such a conclusion that the current approach is not eligible to provide the potential retirement income security to DC members in Korea.

\section{Sensitivity analysis}

The preceding analysis is based on key assumptions such as investment return risk for each asset class, assumed interest rates, wage increase rates, accumulation period and mortality rates. In this section, a sensitivity analysis with respect to the employee's wage increase rate and the accumulation period is conducted.

In the preceding sections, it has been assumed that an employee's wage is subject to annual rises in line with the nominal growth in national average earning, which 
S64

has averaged 7.0 per cent over the 1998 through 2009 data period. To demonstrate the robustness of the previous analysis, lower wage increase rates, say 6 and 5 per cent, are explored. Similar to the PoS in Table 6, the PoS in Table 7 demonstrates that the relative advantage of the alternative approach remains the same.

Table 8 shows the results when the accumulation period is shortened to 20 years from 30 years, and the employee retires at 55. This case is likely to be more realistic because Korean employees retire at an early age from their main job because of the mandatory retirement age system and early retirement programme.

As the accumulated period is decreased by 10 years, terminal wealth in lifecycle funds is significantly less, and thus the benchmark income also reaches a lower level. In comparison to the default case of the 30-year accumulated period, the PoS decreases by 2.3 per cent $\sim 10.2$ per cent points, especially at the 50 per cent VaR.

Consistent with the previous analysis, the sensitivity analysis also confirms that the alternative approach is overall superior to the current approach, particularly on the grounds that the current approach is not able to eliminate the risk of outliving the income stream.

Table 7 Sensitivity analysis with respect to wage increase rates (Unit: Korean won, \%)

\begin{tabular}{|c|c|c|c|c|c|c|}
\hline & \multicolumn{2}{|c|}{$50 \% V_{a} R^{\mathrm{a}}$} & \multicolumn{2}{|c|}{$75 \% \mathrm{VaR}$} & \multicolumn{2}{|c|}{$95 \% \mathrm{VaR}$} \\
\hline & Withdrawal ${ }^{\mathrm{b}}$ & $P o S^{\mathrm{c}}$ & Withdrawal & $\operatorname{PoS}$ & Withdrawal & PoS \\
\hline \multicolumn{7}{|c|}{ Panel A: Wage increase rate $=6 \%$ \& assumed interest rate $\mathrm{d}=4.5 \%$} \\
\hline \multicolumn{7}{|c|}{ In a case of conservative lifecycle fund } \\
\hline Retire at 55 & 179.7 & 58.1 & 124.4 & 33.8 & 76.8 & 12.2 \\
\hline 60 & 332.0 & 69.0 & 227.9 & 43.1 & 138.1 & 17.2 \\
\hline 65 & 623.7 & 79.1 & 417.3 & 54.1 & 253.4 & 24.9 \\
\hline \multicolumn{7}{|c|}{ In a case of aggressive lifecycle fund } \\
\hline Retire at 55 & 189.7 & 59.4 & 114.0 & 26.5 & 59.1 & 4.2 \\
\hline 60 & 360.3 & 76.0 & 212.0 & 36.3 & 106.9 & 6.3 \\
\hline 65 & 696.9 & 85.7 & 393.3 & 48.7 & 195.9 & 10.4 \\
\hline
\end{tabular}

Panel B: Wage increase rate $=5 \%$ \& assumed interest rate $=4.5 \%$

In a case of conservative lifecycle fund

$\begin{array}{rrrrrrr}\text { Retire at } 55 & 158.5 & 48.2 & 108.2 & 34.0 & 65.8 & 9.5 \\ 60 & 291.3 & 71.4 & 196.9 & 44.9 & 116.3 & 16.9 \\ 65 & 540.3 & 81.7 & 354.1 & 56.9 & 208.7 & 24.9\end{array}$

In a case of aggressive lifecycle fund

$\begin{array}{rrrrrrr}\text { Retire at } 55 & 168.1 & 53.2 & 99.9 & 27.6 & 50.6 & 4.4 \\ 60 & 315.4 & 77.5 & 182.5 & 37.8 & 89.3 & 6.4 \\ 65 & 603.8 & 87.3 & 332.1 & 50.4 & 159.0 & 10.0\end{array}$

${ }^{\mathrm{a}} \mathrm{VaR}$ is defined on the basis of the accumulated asset at retirement age.

${ }^{b}$ Withdrawal income from the principal preservation fund is set to be the same amount as the benchmark income provided by (conservative and aggressive) lifecycle funds.

${ }^{c} \mathrm{PoS}$ is the Probability of shortfall.

${ }^{\mathrm{d}}$ Assumed interest rate is the discount rate adopted for converting the accumulated lump sum into immediate constant life annuity.

Source: Authors' calculations. 
Table 8 Sensitivity analysis with respect to accumulation periods (Unit: Korean won, \%)

\begin{tabular}{|c|c|c|c|c|c|c|}
\hline & \multicolumn{2}{|c|}{$50 \% V_{a} R^{\mathrm{a}}$} & \multicolumn{2}{|c|}{$75 \% \mathrm{VaR}$} & \multicolumn{2}{|c|}{$95 \% \mathrm{VaR}$} \\
\hline & Withdrawal ${ }^{\mathrm{b}}$ & $P o S^{\mathrm{c}}$ & Withdrawal & PoS & Withdrawal & PoS \\
\hline \multicolumn{7}{|c|}{ Panel A: Accumulate 20 years \& assumed interest rate $\mathrm{d}^{\mathrm{d}}=4.5 \%$} \\
\hline \multicolumn{7}{|c|}{ In a case of conservative lifecycle fund } \\
\hline Retire at 55 & 58.5 & 50.5 & 42.5 & 21.0 & 27.1 & 6.2 \\
\hline \multicolumn{7}{|c|}{ In a case of aggressive lifecycle fund } \\
\hline Retire at 55 & 60.3 & 55.7 & 39.1 & 15.5 & 21.8 & 2.7 \\
\hline \multirow{2}{*}{\multicolumn{7}{|c|}{$\begin{array}{l}\text { Panel } B: \text { Accumulate } 20 \text { years \& assumed interest rate }=4.0 \% \\
\text { In a case of conservative lifecycle fund }\end{array}$}} \\
\hline & & & & & & \\
\hline Retire at 55 & 55.2 & 48.2 & 40.0 & 17.1 & 25.6 & 9.5 \\
\hline \multicolumn{7}{|c|}{ In a case of aggressive lifecycle fund } \\
\hline Retire at 55 & 56.8 & 53.2 & 36.9 & 13.1 & 20.6 & 2.1 \\
\hline
\end{tabular}

${ }^{\mathrm{a}} \mathrm{VaR}$ is defined on the basis of the accumulated asset at retirement age.

${ }^{b}$ Withdrawal income from the principal preservation fund is set to be the same amount as the benchmark income provided by (conservative and aggressive) lifecycle funds.

${ }^{\mathrm{c}} \mathrm{PoS}$ is the Probability of shortfall.

${ }^{\mathrm{d}}$ Assumed interest rate is the discount rate adopted for converting the accumulated lump sum into immediate constant life annuity.

Source: Authors' calculations.

Lastly, this analysis of simulation outputs can be considered robust because these do not vary significantly from one set of simulation to another.

\section{Conclusions}

Within the DC framework, both asset allocations and payout options have a direct and significant impact on potential retirement income security. The current challenge is to design a new DC framework enhancing the retirement income adequacy for Korean employees who currently rely on the DC plan as a primary source of retirement income.

In this respect, a hypothetical system as an alternative approach to the current Korean DC system is suggested, characterised by strict investment limit restrictions and one-time lump sum payments: that is, a system combining lifecycle funds in the accumulation phase with compulsory annuitisation in the payout phase.

Employing quantitative analysis on the basis of Monte Carlo simulations, it is shown that the hypothetical system is more likely to outperform the current system in the light of potential retirement income security: higher accumulated assets and greater retirement income. On the other hand, an employee under the current system is analysed to be significantly exposed to shortfall/longevity risk due to the lower accumulated assets. Moreover, all these results are re-examined to be robust across all simulated cases by means of sensitivity analysis.

Therefore, it is expected that the results of this study will be adopted as a valuable reference and that they will contribute to the reform of Korean DC plans in 
S66

the near future. Furthermore, the reform direction should be consistent with the implications of this analysis: default options combining lifecycle funds with compulsory annuitisation.

Lastly, to generalise the methodology presented in this paper, the following limitations are considered, and further research should be conducted. First, all the simulation results are based on the limited amount of historical data available over the 1998-2009 period. There exists the possibility that the future stock return and volatility is significantly mismatched with the forward-looking best estimates over long time horizons, due to estimation bias. Accordingly, general conclusions that would be contributable to other countries cannot be suggested here, even though the quantitative analysis and debates would be a valuable lesson, particularly to those countries at the stage of reforming the current DC system, like Korea.

The other limitation is that this analysis does not consider management charges, even though in practice these have a direct and important impact on retirement income planning (currently in Korea charging approximately 5 per cent of a single premium). Thus, further analysis including the charges for annuity (and funds) is required.

\section{References}

Albrecht, P. and Maurer, R. (2002) 'Self-annuitization, consumption shortfall in retirement and asset allocation: The annuity benchmark', Journal of Pension Economics and Finance 3(1): 269-288.

Basu, A. and Drew, M. (2006) Appropriateness of default investment options in defined contribution plans: The Australian evidence, MPRA working paper, from http://mpra.ub.uni-muenchen.de/3314, accessed 1 September 2009.

Bengen, W.P. (1994) 'Determining withdrawal rates using historical data', Journal of Financial Planning 7 : 171-180.

Brinson, G.P., Hood, L.R. and Beebower, G.L. (1986) 'Determinants of portfolio performance', Financial Analysis Journal 42(4): 39-44.

Brinson, G.P., Singer, B. and Beebower, G.L. (1991) 'Determinants of portfolio performance II: An update', Financial Analysis Journal 47(3): 409-448.

Brown, J.R., Kling, J.R., Mullainathan, S. and Wrobel, M.V. (2008) 'Why don't the people insure late life consumption: A framing explanation of under-annuitization puzzle', American Economic Review 98(2): 304-309.

Byrne, A., Blake, D., Cairns, A. and Dowd, K. (2007) 'Default funds in U.K. defined-contribution plans', Financial Analysts Journal 63(4): 40-51.

Drinkwater, H., Sondergeld, T. and Eric, T. (2004) 'Perception of mortality risks: Implications for annuities', in O. Mitchell and S. Utkus (eds.) Pension Design and Structure: New Lessons from Behavioral Finance, New York: Oxford University Press, pp. 275-286.

Dus, I., Maurer, R. and Mitchell, O.S. (2005) 'Betting on death and capital markets in retirement: A shortfall risk analysis of life annuities versus phased withdrawal plans', Financial Services Review 14(3): 169-196.

Ellement, J. and Lucas, L. (2007) 'A retirement adequacy analysis of default options and lifecycle funds', Benefits Quarterly, Third Quarter: 34-45.

Ervin, D.M., Filer, L.H. and Smolira, J.C. (2005) 'International diversification and retirement withdrawals', Mid-American Journal of Business 20: 55-62.

Glickman, M. and Kuehneman, G. (2006) 'Retiree pension payout decisions - Evidence from the Health and Retirement Study, 1992-2002', U.S. Government Accountability Office, from http://www.aeaweb.org/ annual_mtg_papers/2006/0108_0800_0401.pdf, accessed 1 September 2009.

Ibbotson Associates (2005) Stocks, Bonds Bills and Inflation: The 2001 Yearbook, Chicago, IL: Ibbotson Associates.

Korean Ministry of Labor, http://www.moel.go.kr/english/main.jsp.

KSDA-Bloomberg Korean Bond Index, http://www.kofia.or.kr. 
Marcks, C.C. (2009) 'Strengthening target-date funds with guarantees to enhance retirement security', from http://www.prudential.com/media/managed/Target_Date_Fund_with_Income.pdf, accessed 15 September 2009.

Pang, G. (2008) 'Default investment options in defined contribution plans: A quantitative comparison', Pensions 13: 221-226.

Stout, G. and Mitchell, J. (2006) 'Dynamic retirement withdrawal planning', Financial Services Review 15: $117-131$.

Towers Watson (2009) 'Global pension assets survey 2009', from http://www.watsonwyatt.com/asiapacific/localsites/korea/Ideas_and_Research/Business_Issues/Data/2009GlobalPensionStudy.pdf, accessed 30 August 2009.

\section{About the Authors}

Kyonghee Lee is a Research Fellow at the Korea Insurance Research Institute, Seoul, South Korea. She has a PhD in Finance and Korean Actuary and has worked extensively on the analysis of life insurance and pensions.

Jooho Sung is a Professor of Finance \& Insurance at Kyung-Hee University, Seoul, South Korea. He holds a PhD from the Cass Business School, City University (London, U.K.) and is a Korean actuary. His research interests are insurance and pension. 